\title{
The effectiveness of Activity-Based Conceptual Change Modules in Increasing Student Scientific Knowledge and Reducing Students Misconception on Electromagnets
}

\author{
Ni Made Pujani, Ketut Suma, I Wayan Sadia, Ni Ketut Rapi \\ \{pujanimade@yahoo.com, sumaketut@ymail.com, iwayan.sadia@undiksha.ac.id, \\ ketutrapi@yahoo.com\} \\ Universitas Pendidikan Ganesha, Bali, Indonesia
}

\begin{abstract}
This study aims to investigate the effectiveness of the activity-based conceptual change module in increasing the level of scientific knowledge and reducing the level of students' misconception on electromagnets. The participants consisted of 194 high school students from six classes. Three of the classes were assigned randomly as an experimental group and the other classes as a control group. The experimental group gets learning facilitated by activity-based conceptual module, while the control group is given the conventional textbook. The level of scientific knowledge and students' misconception were measured using the Three-Tier Electromagnets Test. The data about the level of scientific knowledge and student misconception were analyzed by the ANCOVA with pretest score used as a covariate. The results showed that the activity-based conceptual change module was effective to increase the level of scientific knowledge and reduce the level of student misconception in the electromagnet.
\end{abstract}

Keywords: activity-based conceptual change module, scientific knowledge, misconception, electromagnets.

\section{Introduction}

Students' knowledge of concepts in physics was an interesting study for the researcher in physics education. Studies showed that students had brought inconsistent misconceptions regarding scientific concepts prior to formal education [1], [2], [3]. Misconceptions hinder a stable cognitive structure [4], making them resistant to change [5], [6], and contribute negatively to learning outcomes [7], [8]. Students' misconceptions about physics are acquired from various sources, such as personal experiences, language used by teachers in classrooms, textbooks, cultural beliefs, and learning practices [9]. Textbooks are an essential component to studying physics, usually designed in the form of expository text format, which is not the best as a tool of conceptual change [10].

In order to overcome the limitation of expository text, a researcher [7] developed a conceptual change text, specifically designed to uncover students' misconceptions about topics and attempt to change them into scientific concepts [11]. Studies [6], [7], [8], [12] and [13] showed that conceptual change text was an effective tool for reducing students' misconceptions. 
The conceptual change texts that had been developed were not originally able to challenge the direct experiences of students. Because of this, and on the advice of [11], the author modified the conceptual change text by adding testing activities in the form of an Activity-Based Conceptual Change Module.

The Activity-Based Conceptual Change Module consists of five parts. The first asks students to explore their prior ideas of concepts in physics so that misconceptions can be identified. The second part expresses general misconceptions or answers that are scientifically incorrect, students are asked to compare these with their own ideas. The third part contains activities for testing students' ideas stated in the first section. The fourth part contains a scientific explanation of the concepts asked in the first section. The fifth part contains statements or opinions of students about the differences between the misconceptions he or she experienced, the results of the test of ideas and scientific explanations obtained from reading the text in the third part and testing his ideas in the fourth part. The sixth part is the section to check the acquisition of student knowledge and drawing conclusions by the teacher. With the physics module based on activity and conceptual change text, students' knowledge is reconstructed in two ways, namely scientific explanation of direct experience.

\section{Purpose of the study}

The purpose of this study was to investigate the effects of Activity-Based Conceptual Change Module, in comparison to the conventional textbook, on the improvement of students' scientific knowledge and reducing their misconceptions on electromagnets. The research questions are as follows:

(1) What is the effect of Activity-Based Conceptual Change Module over a traditional textbook on the improvement of students' conceptual understanding on electromagnets?

(2) What is the effect of Activity-based Conceptual Change Module on reducing students' misconceptions on electromagnets?

\section{Methods}

\subsection{Research design and participant}

This quasi-experimental study was conducted over six weeks with $3 \times 45$ minute sessions per course. The quasi-experimental design was a pretest-posttest non-equivalent control group design. Participants consisted of 194 high school students from six classes enrolled in physics. Three of the classes were assigned randomly as an experimental group and the rest served as a control group. There were 96 total students in the experimental group (EG) and 98 in the control group (CG). The EG received learning facilitated by the Activity-Based Conceptual Module, while the CG was provided with a conventional textbook. The learning process was carried out by high school physics teachers. They were trained on how to use the Activity-Based Conceptual Change Module before implementing it in the class for better accuracy in results. 


\subsection{Data collection}

Information on students' scientific knowledge and misconceptions were collected via the Three Tier Electrostatic Diagnostic Test (TTEDT). The first tier was an ordinary multiplechoice test asking students to choose the right answers out of the alternatives provided. The second tier was a question in which students had to choose the right reason out of the alternative reasons provided. The third tier was to choose the confidence of two alternatives, "sure" and "not sure". Based on the students' response to each tier, conceptions were separated into four categories: scientific knowledge (SK), lack of knowledge (LK), misconception (M) and Error (E). The categorization of students' conception are shown in Table 1.

Table 1. Categorization of Students Conception Based on Their Response to TTEDT

\begin{tabular}{llll}
\hline $\mathbf{1}^{\text {st }}$ tier & $\begin{array}{l}\text { Students' } \\
\mathbf{2}^{\text {nd }} \text { tier }\end{array}$ & $\mathbf{3}^{\text {rd }}$ tier & $\begin{array}{l}\text { Students' } \\
\text { Category }\end{array}$ \\
\hline True & True & Sure & Scientific Knowledge (SK) \\
\hline
\end{tabular}

Learning with conventional textbooks emphasizes transfer of knowledge rather than understanding. Opportunities for reconstruction of student ideas are very limited, especially as the average conventional textbook does not take students' background knowledge into account.

The results of this study are supported by several previous experiments conducted. In the teaching of relativity, Akpinar \& Tan [17] state that the conceptual change text is more effective than traditional text in building conceptual schemes about relativity. In eliminating students' misconceptions of geometric optic, Aydin [12] found that conceptual change text is more effective than traditional methods. Ozkan and Selcuk [7] state that the conceptual change text is very useful for lifelong learning. McKenna [13] states that conceptual change text is the best application of conceptual change models and can be used in every field of science. Cetin, Ertepinar, \& Geban [9] concluded that the influence of text-based teaching conceptual change is better than traditional learning on students' understanding of ecological concepts. Ozkan and Selcuk [18] concluded that understanding experimental buoyancy force concepts are higher than that of the traditional instruction group.

\section{Conclusion}

The use of Activity-Based Conceptual Change Module in physics has a particular value for physics teachers and students alike. Unlike conventional textbooks, Activity-Based Conceptual Change takes students' prior knowledge into account. They are considered more effective than conventional books in developing students' scientific knowledge and reducing misconceptions regarding the electromagnet. Physics teachers are encouraged to use Activity-Based Conceptual 
Change Modules as supplementary teaching materials during electromagnet instruction in high school.

\section{References}

[1] Demirci, N: A Study about students' misconceptions in force and motion concepts by incorporating a web-assisted physics program. The Turkish Online Journal of Educational Technology-TOJET. Vol 4 Issue 3 Article 7, pp 40-48 (2005).

[2] Sekercioglu, A.G., and Kokakulah, M.S.: Grade 10 students' misconceptions about impulse and momentum. Journal of Turkish Science Education. Vol 5, Issue 2, pp 47-59 (2008)

[3] Gonen, S., and Kocakaya, S.: A physics lesson designed according to 7E model with the help of instructional technology (lesson plan). Turkish Online Journal of Distance Education-TOJDE. Vol: 11(1), pp: 98-113 (2010).

[4] Sencar, S., \& Eryilmaz, A.: Factors mediating the effect of gender on ninth-grade Turkish students' misconceptions concerning electric circuits. Journal of Research in Science Teaching: The Official Journal of the National Association for Research in Science Teaching, 41(6), pp 603-616. (2004).

[5] Sungur, S., Tekkaya, C., \& Geban, O.: The contribution of conceptual change texts accompanied by concept mapping to students' understanding of the human circulatory system. School Science and Mathematics, Vol 101,pp 91-101 (2001).

[6] Celikten, O., İpekçioğlu, S., Ertepınar, H., Geban, O.: The effect of the conceptual changeoriented instruction through cooperative learning on 4th-grade students' understanding of earth and sky concepts.Science Education International, Vol 23 (1),pp 84-96 (2012).

[7] Ozkan, G., \& Selcuk, G.S.: The use of conceptual change text as class material in the teaching of sound in physics. Asia Pacific Forum on Science Learning and Teaching. Vol. 14, Issue 1, pp 122 (2013).

[8] Gürefe, N., Yarar, S.H., Pazarbasi, B.N., \& Es,H.: The effect of conceptual change texts on an understanding of height concept of secondary school 5th Class Students. International Journal of Educational Studies in Mathematics, Vol 1 (1), pp 58-68 (2014)

[9] Cetin, G., Ertepinar, H., \& Geban, O.: Effect of conceptual change text-based instruction on ecology, attitude toward biology and environmental. Educational Research and Review, Vol 10(3), pp 259-273(2015).

[10] Guzzeti, B.J., Snyder, T.E., Glass, G.V., and Games, W.S.: Meta-analysis of instructional interventions from reading education and science education to promote conceptual change in science. Reading Research Quarterly, Vol 28, pp 116-161 (2013)

[11] Cetingul, I., \& Geban, O.: Using conceptual change texts with analogies for misconception in acids and bases, H.U Journal of Education, Vol 41, pp 112-123 (2011).

[12] Aydin, S.: Remediation of misconception about geometric optics using conceptual change texts. Journal of Education Research and Behavioral Science, Vol 1(1), pp 001-012. (2011).

[13] McKenna, D.M.: Using Conceptual Change Texts to Address Misconceptions in the Middle School Science Classroom. Education and Human Development Master's Theses. Paper 521. (2014) [14] Kaltakçi, D, and Nilüfer, D.: Identification of Pre-Service Physics Teachers' Misconceptions on Gravity Concept: A Study with a 3-Tier Misconception Test Sixth Int. Conf. of the Balkan Physical Union (American Institute of Physics), p499 (2007).

[15] Dahar, R.W.: Teori-Teori Belajar \& Pembelajaran. Jakarta: Erlangga. p 164 (2006)

[16] Posner, G. J., Strike, K. A., Hewson, P.W and Gertzog, W.A .: Science Education Vol 66, pp 211-227 (1982). 
[17] Akpinar, M,. and Tan, M.: Developing , implementing , and testing a conceptual text about relativity. Western Anatolia Journal of Educational Sciences (WAJES). Special Issue, pp139-144 (2011)

[18] Ozkan, G., and Selcuk, G. S.: How effective is "conceptual change approach" in teaching? Universal Journal of Educational Research, Vol 2(2), 3981-988 (2015) 